\title{
Population structure, races, and host range of Aphanomyces euteiches from alfalfa production fields in the central USA
}

\author{
Dean K. Malvick • Niklaus J. Grünwald • \\ Alan T. Dyer
}

Received: 22 March 2008 / Accepted: 7 July 2008 / Published online: 31 July 2008

(C) KNPV 2008

\begin{abstract}
Aphanomyces euteiches (races 1 and 2) causes root rot of alfalfa; however, its population biology and distribution are poorly understood where alfalfa is a major crop. The objectives of this study were to (1) characterise the distribution and frequency of races of $A$. euteiches in Illinois alfalfa fields, (2) determine host range of $A$. euteiches on cultivated and native legumes, and (iii) to describe genetic diversity and population genetic structure of $A$. euteiches in alfalfa fields. To accomplish this, soil samples $(n=$ 103) were collected from 30 alfalfa fields in 18 Illinois counties. Using the susceptible cv. 'Saranac', 148 isolates of A. euteiches were baited from the soil. The virulence phenotype of isolates representing all 18 counties was tested, and $54 \%$ were $\mathrm{R} 1$ and $46 \%$ were R2. Both races were detected in $61 \%$ of the counties, whereas only R1 was detected in $22 \%$ and $\mathrm{R} 2$ in $17 \%$. Thirteen legume hosts for isolates from
\end{abstract}

D. K. Malvick $(\bowtie)$

Department of Plant Pathology, University of Minnesota,

St. Paul, MN 55108, USA

e-mail:dmalvick@umn.edu

N. J. Grünwald

Horticultural Crops Research Laboratory, USDA-ARS,

Corvallis, OR 97330, USA

A. T. Dyer

Department of Plant Sciences and Plant Pathology,

Montana State University,

Bozeman, MT 59717, USA alfalfa fields were identified based on symptoms and/ or production of oospores in roots. In addition to six previously known hosts, seven species were susceptible to infection: kura clover, purple prairie clover, white prairie clover, ladino clover, hairy vetch, Canadian milk vetch, and Illinois tick trefoil. AFLP analysis revealed high levels of genetic diversity among the isolates from different fields and counties and a lack of genetic structuring of populations based on race or geographical origin. The results suggest that populations of $A$. euteiches in alfalfa fields are diverse, often composed of races 1 and 2, and create risk for alfalfa and to multiple cultivated and native legume species.

Keywords Medicago · AFLP. Population · Diversity · Legume $\cdot$ Root $\cdot$ Host

\section{Introduction}

Aphanomyces root rot was first recognised as an important disease of alfalfa (Medicago sativa) in the US during the 1980s, and isolates of A. euteiches that infect alfalfa have since been reported from Australia, Canada, France, and Sweden (Abbo and Irwin 1990; Delwiche et al. 1987; Levenfors et al. 2003; Richard and Martin 1991). Aphanomyces root rot of legumes typically begins during the seedling stage under poorly-drained soil conditions (Papavizas and Ayers 1974; Stuteville and Erwin 1990). The disease can 
progress resulting in damping-off, light-brown discolouration and rot of root and hypocotyl tissues, stunting, chlorosis, reduced nodulation and, in the case of alfalfa, increased winter damage (Grau et al. 1991; Wiersma et al. 1997). Management of Aphanomyces root rot of legumes is based on the use of diseaseresistant cultivars and avoiding poorly-drained soils (Grünwald et al. 2004; Stuteville and Erwin 1990).

The crops considered to be most susceptible to Aphanomyces root rot in the US are pea (Pisum sativum), alfalfa (M. sativa), snap bean (Phaseolus vulgaris), and red clover (Trifolium pratense) (Delwiche et al. 1987; Grünwald et al. 2004; Papavizas and Ayers 1974; Holub et al. 1991; Stuteville and Erwin 1990; Tofte et al. 1992). Isolates of A. euteiches are variable in pathogenicity and virulence on these different host species, and host preference among isolates has been reported. Subspecific groups with host preference for pea, alfalfa, bean, pea/alfalfa, and alfalfa/red clover are known, and a forma specialis has been reported for bean (Delwiche et al. 1987; Grau et al. 1991; Holub et al. 1991; Levenfors et al. 2003; Malvick et al. 1998; Malvick and Percich 1998; Wicker et al. 2003). Isolates of $A$. euteiches that vary in virulence to different cultivars within a host species have also been reported in the form of physiological specialists on pea and races on pea and alfalfa (Grau et al. 1991; Malvick and Grau 2001; Malvick and Percich 1998; Wicker et al. 2001).

Despite frequent and undiagnosed problems with stand establishment, persistence, and low yields of alfalfa, the importance of Aphanomyces root rot and the characteristics of Aphanomyces populations in alfalfa fields have been unexplored in most areas in the US. This includes many states in the central US such as Illinois, where alfalfa is the third or fourthlargest crop based on land area in production. Isolates of $A$. euteiches that infect alfalfa in North America have been reported from 13 U.S. states and Quebec, Canada (Beghdadi et al. 1992; Delwiche et al. 1987; Grau et al. 1991; Malvick 2002; Munkvold and Carlton 1995; Vincelli et al. 1994). The isolates that were initially reported from alfalfa were designated race 1 (R1). They were highly virulent on the susceptible alfalfa cv. Saranac and expressed low virulence on WAPH-1 (Grau et al. 1991; Malvick and Grau 2001). WAPH-1 is an alfalfa population with resistance to R1 isolates and is similar to much of the resistance available initially in commercial cultivars
(Grau 1992; Vandemark et al. 2004). Isolates of $A$. euteiches were identified later that were virulent on Saranac and WAPH-1, and were designated race 2 (R2) (Grau et al. 1991; Malvick and Grau 2001). An alfalfa population (WAPH-5) with resistance to race 2 was also developed (Fitzpatrick et al. 1998).

Limited studies on the distribution and frequencies of A. euteiches and its two races (R1 and R2) have been conducted in Wisconsin, Iowa, Kentucky, and Minnesota (Malvick and Grau 2001; Munkvold and Carlton 1995; Vincelli et al. 1994). In Wisconsin, this pathogen was isolated from $100 \%$ of nine alfalfa fields sampled as well as from fields with no history of alfalfa production (Malvick and Grau 2001). From fields in Wisconsin with a history of alfalfa production, $57 \%$ of isolates were R1 and $43 \%$ were R2 (Malvick and Grau 2001). In Iowa, A. euteiches was detected in 31 of 45 counties and in $74 \%$ of alfalfa fields that were sampled, and 14 of 14 isolates tested from 11 counties were R2 (Munkvold and Carlton 1995; Munkvold et al. 2001). In Kentucky, alfalfainfecting isolates of $A$. euteiches were detected in 47 counties and in $57 \%$ of the fields sampled (Vincelli et al. 1994). In one field in Kentucky, both R1 and R2 isolates were detected (Malvick and Grau 2001). All isolates tested from four fields in Minnesota were race 2 (Malvick and Grau 2001). These studies suggested that R2 isolates may be a common risk to commercial cultivars that are resistant only to R1. However, the distribution and characteristics of the races associated with alfalfa were unknown in most areas.

Host range of $A$. euteiches from alfalfa has been studied, although isolates from pea have been the focus of most host range studies (Delwiche et al. 1987; Grau et al. 1991; Papavizas and Ayers 1974; Richard and Martin 1991). Regional differences have been reported for the host range among isolates from pea fields. For example, $18 \%$ of isolates from Minnesota pea fields infected alfalfa but it was $97 \%$ for isolates from Wisconsin (Holub et al. 1991; Malvick and Percich 1998). Similar information is not available for isolates from alfalfa. Alfalfa is often rotated with vegetable or other forage legumes, hence, the host range may not only indicate which legumes are at risk if planted in alfalfa fields infested with $A$. euteiches, but also which legumes may increase the risk of Aphanomyces root rot to alfalfa. This information may also indicate which prairie legumes are possible origins of $A$. euteiches populations that infect 
alfalfa and other crop species in fields that were once native prairies. The following legumes have been reported to be infected by isolates of $A$. euteiches from alfalfa: alfalfa, pea ( $P$. sativum), bean $(P$. vulgaris), red clover (T. pratense), white clover ( $T$. repens), white sweet clover (Melilotus alba), yellow sweet clover (M. officinalis), berseem clover ( $T$. alexandrinum), and garden beet (Beta vulgaris; Beghdadi et al. 1992; Delwiche et al. 1987; Grau et al. 1991; Holub et al. 1991).

A more fundamental understanding of $A$. euteiches populations associated with alfalfa was also lacking. Neither the population genetic structure in alfalfa fields, nor the genotypic relationships between races 1 and 2 have been explored. Studies of the population biology of $A$. euteiches have been restricted to isolates from pea fields in a few U.S. states. For isolates from pea fields in Minnesota and Oregon, genotypic variation in populations within and among fields was identified and genotypic markers were associated with pathogenicity traits (Malvick and Percich 1998). Moderately high genetic diversity existed within populations of $A$. euteiches in individual fields in Washington and Oregon, and populations were differentiated among fields (Grünwald and Hoheisel 2006). The results suggested that the population structure of $A$. euteiches from pea fields is driven by selfing via oospores, although both sexual and asexual reproduction may occur. Similar analyses of populations of $A$. euteiches from perennial alfalfa fields have not been conducted, although two genotypes were identified among a small group of isolates from Wisconsin alfalfa fields (Malvick et al. 1998).

Aphanomyces root rot is an important disease of alfalfa; however, the distribution and biology of the two races of $A$. euteiches in alfalfa fields are poorly understood. Several hypotheses were addressed in this study: (1) A. euteiches occurs more commonly and is more widely distributed in alfalfa fields than previously known; (2) races 1 and 2 of $A$. euteiches occur in alfalfa fields in relative frequencies that vary by location; (3) the host range of isolates of $A$. euteiches from alfalfa fields includes a wider array of cultivated and native legumes than was documented; and (4) the population of $A$. euteiches in alfalfa fields is genetically diverse and differentiated based on race and region. This is the most extensive study conducted on populations of $A$. euteiches from alfalfa fields. It addresses disease resistance and crop rotation, and provides insights into the risks, population biology, and origin of this pathogen in Midwestern prairies.

\section{Materials and methods}

Collection of soil samples and isolation of $A$. euteiches

Soil samples $(n=103)$ were collected from 30 alfalfa fields in 18 Illinois counties ( 1 to 6 fields per county; Fig. 1 and Table 1). These 18 counties represented approximately $40 \%$ of the total alfalfa acreage in Illinois. About $50 \%$ of the alfalfa fields were selected because they had a history of seedling establishment problems, thinning, or stunted growth, and the others were selected arbitrarily. All of the fields had a history of frequent alfalfa production with corn as the most common rotational crop, and few fields had a history of occasional rotation with soybean or wheat. None had a history of pea production. Based on the availability of R1-resistant alfalfa cultivars and reports from alfalfa producers, $<50 \%$ of the fields sampled had a history of alfalfa cultivars with resistance to Aphanomyces root rot. Three or four separate soil samples were collected arbitrarily from each field to a depth of 10-14 cm, then placed into separate plastic bags and stored at $6^{\circ} \mathrm{C}$. The soil types sampled were variable among the fields but all had a moderate to high clay content. The alfalfa cv. 'Saranac' was used to bait $A$. euteiches from the soil, and $A$. euteiches was isolated from infected roots as described previously (Delwiche et al. 1987; Grau et al. 1991; Malvick and Grau 2001). The identity of isolates as A. euteiches was confirmed based on morphological features (Delwiche et al. 1987; Malvick and Percich 1998). In many cases, multiple plants were infected and several isolates were obtained from a single soil sample; however, only one isolate from one infected seedling from each soil sample was used for subsequent analyses. Single-zoospore subcultures were obtained from each field isolate for all analyses and stored on corn meal agar (CMA) at $8^{\circ} \mathrm{C}$ (Malvick et al. 1998).

Pathogenicity and virulence phenotype testing

The virulence phenotype of 148 isolates of $A$. euteiches was tested on Saranac, WAPH-1, and 
Fig. 1 Counties in Illinois (shaded) where A. euteiches was detected in alfalfa fields. These represent all 18 counties that were sampled in this study

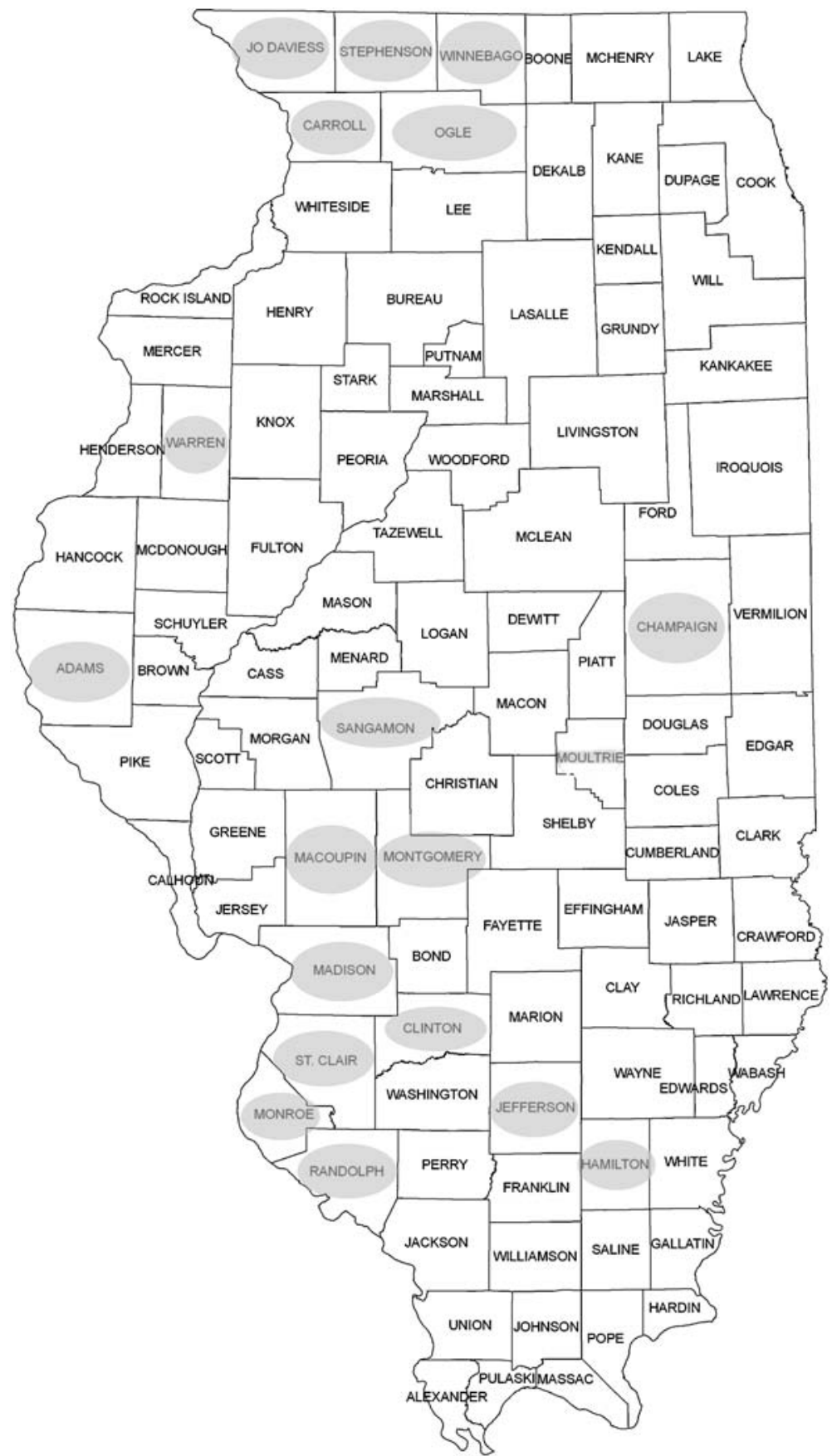

WAPH-5 alfalfa populations in greenhouse assays as described previously (Delwiche et al. 1987; Fitzpatrick et al. 1998; Grau et al. 1991; Malvick and Grau 2001). Saranac is susceptible to all races of $A$. euteiches and was used to confirm pathogenicity. WAPH-1 is resistant to race 1 (R1) isolates and susceptible to race 2 (R2) isolates, and WAPH-5 is resistant to R1 and R2 isolates of A. euteiches (Fitzpatrick et al. 1998; Grau 1992; Grau et al. 1991; Malvick and Grau 2001). Zoospores were produced for inoculations from all isolates as described previously (Malvick et al. 1998). The isolates MF-1 (a R1 check isolate) and NC-1 (a R2 check isolate) were also used in all inoculation experiments 
Table 1 Summary of information about isolates of Aphanomyces euteiches analysed from Illinois

\begin{tabular}{|c|c|c|c|c|c|c|}
\hline County $^{\mathrm{a}}$ & $\begin{array}{l}\text { Fields with isolates } \\
\text { per county }\end{array}$ & $\begin{array}{l}\text { Isolates in } \\
\text { race analysis }\end{array}$ & $\begin{array}{l}\text { Isolates in } \\
\text { AFLP analysis }\end{array}$ & $\begin{array}{l}\text { Isolates in host } \\
\text { range analysis }\end{array}$ & Race 1 isolates $^{\mathrm{b}}$ & Race 2 isolates ${ }^{b}$ \\
\hline Adams (w) & 3 & 20 & 7 & 1 & 9 & 11 \\
\hline Carroll (n) & 1 & 9 & 6 & 0 & 6 & 3 \\
\hline Champaign (e) & 3 & 13 & 11 & 0 & $0 *$ & $13^{*}$ \\
\hline Clinton (e) & 1 & 3 & 2 & 2 & $0 *$ & $3 *$ \\
\hline Hamilton (s) & 1 & 2 & 2 & 0 & 2 & 0 \\
\hline Jefferson (s) & 2 & 6 & 4 & 0 & $5 *$ & $1 *$ \\
\hline Jo Davies (n) & 1 & 14 & 4 & 1 & 9 & 5 \\
\hline Macoupin (s) & 1 & 8 & 5 & 1 & 6 & 2 \\
\hline Madison (s) & 1 & 7 & 4 & 1 & $7 *$ & $0 *$ \\
\hline Monroe (s) & 1 & 6 & 2 & 1 & 4 & 2 \\
\hline Montgomery (s) & 6 & 25 & 15 & 0 & 14 & 11 \\
\hline Ogle (n) & 1 & 2 & 2 & 0 & 2 & 0 \\
\hline Randolph (s) & 1 & 6 & 1 & 0 & 4 & 2 \\
\hline Sangamon (s) & 1 & 5 & 5 & 0 & $5 *$ & $0 *$ \\
\hline St. Clair & 1 & 2 & 0 & 0 & 0 & 2 \\
\hline Stephenson & 1 & 3 & 0 & 0 & 2 & 1 \\
\hline Warren (w) & 3 & 7 & 5 & 1 & 4 & 3 \\
\hline Winnebago (n) & 1 & 10 & 3 & 0 & 4 & 6 \\
\hline Totals: 18 & 30 & 148 & 78 & 8 & $83 *$ & $65^{*}$ \\
\hline
\end{tabular}

${ }^{\mathrm{a}}$ Letter in parentheses indicates the region (west, north, east, or south) that each county was placed into for AFLP population analysis.

${ }^{\mathrm{b}}$ Race 1 and 2 values for a county followed by $*$ are significantly different from each other based on Fishers exact test $(P<0.05)$.

(Fitzpatrick et al. 1998; Grau et al. 1991; Malvick and Grau 2001; Malvick et al. 1998). Pots (5 cm) containing 5 day-old seedlings grown in vermiculite were flooded, inoculated with 500 zoospores/seedling, and kept saturated with water for 4 days after inoculation in a greenhouse at $22-26^{\circ} \mathrm{C}$ with a $14-$ $\mathrm{h}$ photoperiod. Non-inoculated plants of each cultivar were maintained as controls. The vermiculite was drained and adequate moisture for good growth was maintained for an additional 10-11 days at the same temperature and photoperiod. Plants were fertilised with a $1 \mathrm{X}$ soluble nutrient solution (Peters Professional ${ }^{\circledR}$ General Purpose, J.R. Peters, Allentown, PA) 6 days after inoculation. Three replications, each with 20 seedlings, were used for each combination of isolate by alfalfa population in a randomised block design. Three adjacent pots in a tray, each containing 6-8 seedlings, were considered as one replicate. These experiments were conducted twice.

Disease severity was determined by scoring individual plants 19-20 days after sowing on a 1 to 5 scale, where 1 is an asymptomatic plant and 5 is dead, and calculating an average disease severity index
(ASI; Fitzpatrick et al. 1998; Grau et al. 1991). ASI values of $\geq 3.0$ were considered susceptible reactions, and $<3.0$ were considered resistant (Grau et al. 1991, Malvick and Grau 2001). Isolates were placed into the two races based on the interaction phenotypes as measured by the ASI level in inoculated plants. The ASI for R1 isolates was $>3$ for Saranac and $<3$ for WAPH-1, and the ASI for R2 isolates was $>3$ for Saranac and WAPH-1 (Malvick and Grau 2001; Munkvold et al. 2001). The numbers of R1 and R2 isolates detected in each county were tested for significant differences $(P<0.05)$ using Fishers exact test (Steel et al. 1997).

Host range studies with isolates of $A$. euteiches

Fifteen cultivated and native legume species that may be grown, or may have grown, in the same fields as alfalfa were used in host-range studies. Each plant species was inoculated with ten isolates of $A$. euteiches, eight from Illinois (five R1 and three R2 isolates) and the check R1 isolate MF1 and the check $\mathrm{R} 2$ isolate $\mathrm{NC} 1$ to test which species can host $A$. 
euteiches isolates from alfalfa (Tables 1 and 2). Sowing, growth, and inoculation procedures were essentially as described above for alfalfa. When seedlings were $2-3 \mathrm{~cm}$ tall they were inoculated with 600 zoospores per plant and maintained in a greenhouse at $22-26^{\circ} \mathrm{C}$ with a 14 -h photoperiod. Noninoculated plants of each cultivar were maintained as controls. Plants were harvested and washed 1922 days after sowing, and roots were scored for symptoms and severity of Aphanomyces root rot as noted above. In addition, roots from three plants of each species that had been inoculated with each isolate were crushed flat, stained with cotton blue, and examined microscopically for the presence of Aphanomyces oospores. Root tissue from two plants of each host species containing oospores was also placed on CMA medium to isolate the pathogen and confirm that plants containing oospores were infected with $A$. euteiches. This experiment was conducted twice.
Amplified fragment length polymorphism (AFLP) genotyping

AFLP was performed on genomic DNA of $A$. euteiches using the AFLP Microbial Fingerprinting protocol (Applied Biosystems (ABI), Foster City, CA) with slight modifications as described previously (Grünwald and Hoheisel 2006). Isolates of $A$. euteiches included in the AFLP analysis included 78 isolates from alfalfa fields in 16 Illinois counties as well as representative alfalfa isolates from Wisconsin and North Carolina, pea isolates from Wisconsin and Minnesota, and one isolate of $A$. cochlioides from Minnesota (Table 1). DNA (20 ng) was digested, adaptors were ligated, and preselective amplifications with EcoRI core primer, MseI core primer and AFLP amplification core mix were performed on a GeneAmp 9700 thermal cycler (ABI) as described (Grünwald and Hoheisel 2006). Pre-amplified samples $(10 \mu \mathrm{l})$ were diluted with $190 \mu \mathrm{l}$ of TE buffer and

Table 2 Cultivated and native legume species tested for susceptibility to ten isolates of $A$. euteiches collected from alfalfa fields

\begin{tabular}{|c|c|c|c|c|}
\hline Host & Cultivar & Latin name & Oospores in roots ${ }^{\mathrm{a}}$ & ARR symptoms ${ }^{\mathrm{a}}$ \\
\hline Alfalfa & Saranac $^{\mathrm{b}}$ & Medicago sativa & + & + \\
\hline Pea & Little Marvel $^{\mathrm{c}}$ & Pisum sativum & + & + \\
\hline Snap bean & Early Gallatin ${ }^{\mathrm{d}}$ & Phaseolus vulgaris & + & + \\
\hline Red clover & Marathon $^{\mathrm{e}}$ & Trifolium pratense & + & + \\
\hline Berseem clover & Unknown $^{\mathrm{e}}$ & Trifolium alexandrinum & + & + \\
\hline Crimson clover & Dixie $^{\mathrm{e}}$ & Trifolium incarnatum & + & + \\
\hline Kura clover & Unknown $^{\mathrm{e}}$ & Trifolium ambiguum & + & + \\
\hline Purple prairie clover & Unknown $^{\mathrm{f}}$ & Dalea purpurea & + & + \\
\hline White prairie clover & Unknown $^{\mathrm{g}}$ & Dalea candida & - & + \\
\hline Ladino clover & Seminole $^{\mathrm{e}}$ & Trifolium repens & + & + \\
\hline Hairy vetch & Unknown $^{\mathrm{h}}$ & Vicia villosa & + & + \\
\hline Canadian milk vetch & Unknown $^{\mathrm{g}}$ & Astragalus canadensis & + & + \\
\hline Illinois tick trefoil & Unknown ${ }^{\mathrm{g}}$ & Desmodium illinoense & + & + \\
\hline Birdsfoot trefoil & Norcen $^{\mathrm{e}}$ & Lotus corniculatus & - & - \\
\hline Partridge pea & Unknown $^{\mathrm{g}}$ & Chamaecrista fasciculata & - & - \\
\hline
\end{tabular}

${ }^{a}$ If two or more plants had an average disease severity index $\geq 3$ and/or oospores were detected microscopically with one or more isolates approximately 3 weeks after inoculation, a species was rated as a host (+), otherwise it was rated as a non-host (-).

${ }^{\mathrm{b}}$ Source of seed, Western Regional Plant Introduction Station, Pullman, WA 99164, USA.

${ }^{\mathrm{c}}$ Source of seed, Burpee Seed Company, Warminster, PA 18974, USA.

${ }^{\mathrm{d}}$ Source of seed, Harris Moran Seed Company, Modesto, CA 95352, USA.

${ }^{\text {e }}$ Source of seed, Albert Lea Seed House, Albert Lea, MN 56007, USA.

${ }^{\mathrm{f}}$ Source of seed, Aggasiz Seed and Supply, West Fargo, ND 58078, USA.

${ }^{\mathrm{g}}$ Source of seed, Oak Prairie Farm, Pardeeville, Wisconsin 53954, USA.

${ }^{\mathrm{h}}$ Source of seed, G. Bollero, University of Illinois, Urbana, IL 61801 USA. 
selective PCR was performed with dye-labelled MseICT primer, EcoRI-AT primer, and AFLP core amplification mix (ABI) as described previously (Grünwald and Hoheisel 2006). Products (0.5 $\mu$ l) were run with $25 \mu \mathrm{l}$ of loading buffer $(24 \mu \mathrm{l}$ of deionised formamide and $0.05 \mu \mathrm{l}$ of GeneScan-500 size standard, $\mathrm{ABI}$ ) on a capillary sequencer (ABI Prism 3100). Electropherograms were analysed using GeneMapper software (version 3.7; ABI) to extract a matrix of presence and absence of alleles in a range of 50 to $500 \mathrm{bp}$ after visual inspection for further downstream analysis. All AFLP analyses were replicated two or more times including independent DNA extractions and PCR reactions until all polymorphic alleles could be binned unambiguously.

\section{AFLP data analysis}

Populations were defined by region (north, south, east, west) in Illinois as presented in Table 3. Population structuring was investigated by analysing allele frequencies, heterozygosity, genetic distance and genetic differentiation (Grünwald et al. 2001, 2003; Grünwald and Hoheisel 2006). A multilocus genotype was constructed for each isolate by combining data for single AFLP alleles (Grünwald et al. 2003). Alleles were treated as dominant markers and frequencies were estimated based on Lynch and Milligan's (1994) Taylor expansion estimate. Of the 144 alleles scored, only 124 were retained for analysis after removing rare $(<3 \%$ frequency) or fixed alleles. Unbiased expected heterozygosities (Nei 1978) were calculated using TFPGA (Tools for Population Genetic Analyses, version 1.3; Department. of Biological Science,
Northern Arizona University, Flagstaff, AZ). Weir's $F_{\mathrm{ST}}$ values were also calculated using TFPGA (Weir 1996). Exact tests for population differentiation were determined using a Monte Carlo approach (ten batches, 2,000 permutations per batch and 1,000 dememorisation steps) as described in the TFPGA manual. A tree was constructed using the unweighted pair-group method of averages (UPGMA) algorithm from Roger's modified genetic distance matrix (Wright 1978). Statistical support for phenogram branches shown only for values $>70 \%$ was obtained using 1,000 bootstrapped samples using TFPGA. Trees were visualised in MEGA (Tamura et al. 2007) using a distance matrix produced by TFPGA and were rooted with $A$. cochlioides.

\section{Results}

Occurrence and race phenotypes of $A$. euteiches in alfalfa fields

Aphanomyces euteiches was detected in all 18 counties sampled (Fig. 1). This pathogen was detected in one to six fields per county, from a total of 30 alfalfa fields and $85 \%$ of soil samples tested (Table 1). All isolates were pathogenic on Saranac alfalfa. Both races were common across Illinois; $54 \%$ of the isolates were race $1(\mathrm{R} 1)$ and $46 \%$ were race 2 (R2; Table 1). R1 and R2 were detected in $61 \%$ of the 18 counties sampled, whereas R1 only was detected in $22 \%$ of the 18 counties and R2 only was detected in $17 \%$ of the counties. Approximately $5 \%$ of the isolates were virulent (ASI $>3$ ) on the alfalfa germplasm WAPH-5.

Table 3 Analysis of AFLP data for Aphanomyces euteiches isolates by population from alfalfa fields in Illinois

\begin{tabular}{|c|c|c|c|c|c|}
\hline Population & Counties & $N$ & $P(\%)$ & $G$ & Het \\
\hline North & Carroll, Jo Davies, Ogle, Winnebago & 15 & 26.6 & 15 & 0.0861 \\
\hline West & Adam, Warren & 12 & 32.3 & 12 & 0.1033 \\
\hline East & Champaign, Clinton & 11 & 24.2 & 11 & 0.0708 \\
\hline South & Hamilton, Jefferson, Macoupin, Madison, Monroe, Montgomery, Randolph, Sangamon & 40 & 37.9 & 39 & 0.0809 \\
\hline$(\mathrm{WI})^{\mathrm{a}}$ & - & 4 & 14.5 & 4 & 0.0698 \\
\hline Average & - & 78 & 61.3 & 81 & 0.0996 \\
\hline
\end{tabular}

$N$ Sample size, $P$ percentage of loci that are polymorphic, $G$ number of genotypes observed, Het unbiased expected heterozygosity (Nei 1978),

${ }^{\text {a }}$ Data for four individuals sampled in Wisconsin (WI) are shown for comparison but were not included in population analyses. 
Host range of isolates of $A$. euteiches on different legume genera and species

Based on symptoms of Aphanomyces root rot and/or the presence of oospores in root tissue of seedlings following inoculation, 13 legume hosts were infected by $A$. euteiches (Table 2). For the following seven legume species, this is the first report of their susceptibility to infection by $A$. euteiches isolates from alfalfa fields: kura clover, purple prairie clover, white prairie clover, ladino clover, hairy vetch, Canadian milk vetch, and Illinois tick trefoil. Rot symptoms and oospores typical of $A$. euteiches were observed in root tissue for 12 of the legumes, but for white prairie clover, symptoms of Aphanomyces root rot were observed without oospores observed in the roots. Birdsfoot trefoil and partridge pea had neither oospores nor symptoms detected, and were considered to be non-hosts. Aphanomyces euteiches was isolated from root tissues of all hosts containing oospores and/ or with symptoms. Each of the hosts identified was infected by both R1 and R2 isolates, except for hairy vetch which was infected only by R1 isolates. Neither oospores nor root rot symptoms were observed in non-inoculated plants for each legume species

Population biology and diversity among isolates based on AFLP analysis

Analysis of multilocus AFLP genotypes revealed high genetic diversity and low to moderate differentiation among isolates of $A$. euteiches from alfalfa fields at the regional level within Illinois. With the exception of two isolates obtained in Montgomery County, all isolates were of a unique genotype (Table 3). Heterozygosity was moderate, ranging from 0.07 to 0.1 (Table 3). Populations of $A$. euteiches were not significantly differentiated by region based on the exact test $\left(F_{\mathrm{ST}}=\right.$ $0.1141 ; P=0.5867)$. The populations lacked structure given the lack of bootstrap support in the cluster analysis (Fig. 2). Populations also showed low and non-significant differentiation by race $\left(F_{\mathrm{ST}}=0.0570\right.$; $P=1.0$ ), high genotypic diversity (43 multilocus genotypes out of 44 isolates were race 1 and 36 out of 36 were race 2), and no relationship between race and genotype was apparent in the cluster analysis (Fig. 2). While the pea isolates from Wisconsin clustered together (Fig. 2), they did not cluster separately from and were commingled with isolates from alfalfa.

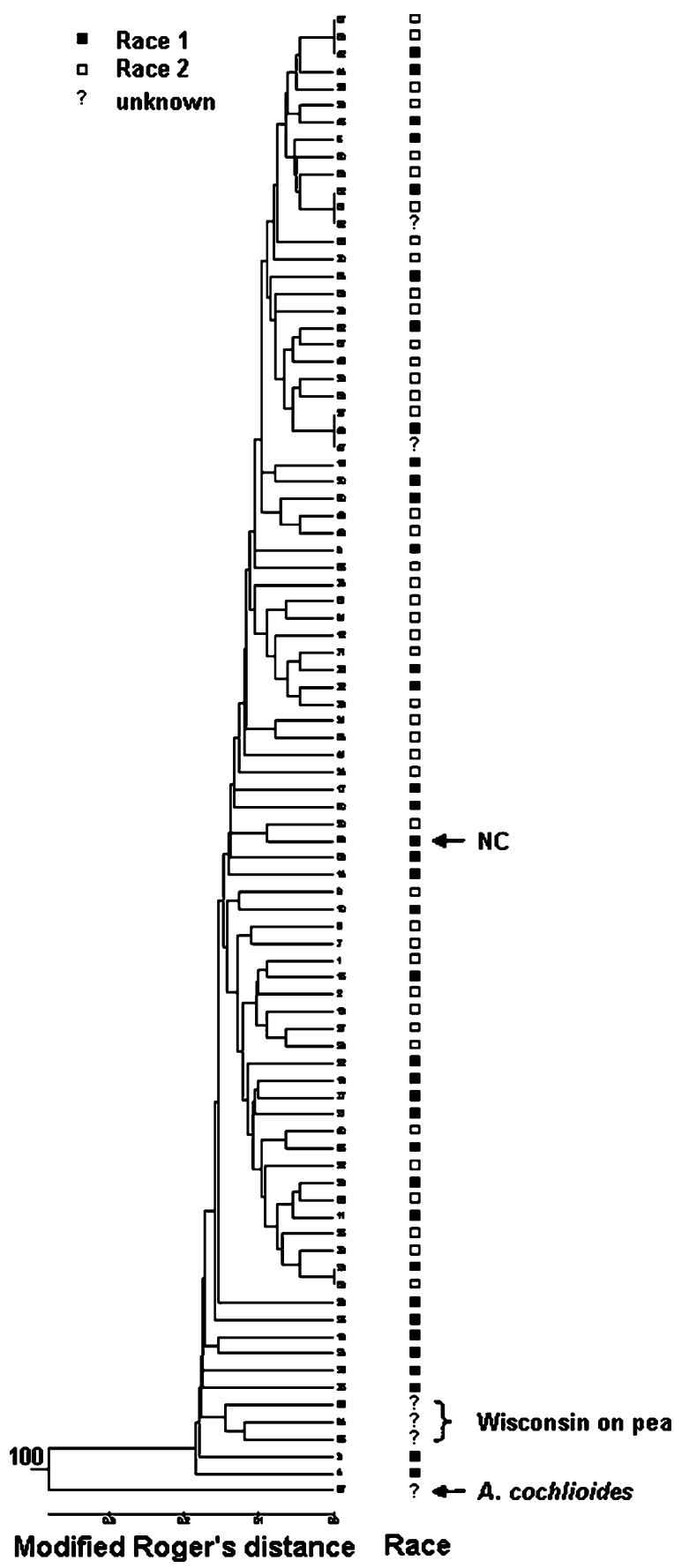

Fig. 2 Relationship between A. euteiches populations in alfalfa based on Rogers's modified genetic distance calculated for AFLP allele frequencies. Race is shown as filled square race 1; empty square race 2; and question mark race unknown or could not be determined. The number at the major phenogram branch indicate statistical support $>70 \%$ using 1,000 bootstrapped samples, whereas other bootstrap support values were $<70 \%$ and are not shown 


\section{Discussion}

Aphanomyces root rot is an important cause of poor stand establishment and reduced yields for alfalfa and other legumes. In this study A. euteiches was detected in 30 fields from all 18 counties sampled in the primary alfalfa production areas of Illinois, a state central and representative to the Midwestern alfalfa production region. This is the first report demonstrating that this pathogen is distributed widely in Illinois across multiple soil series and environments. Previous reports have suggested that this pathogen is common in Iowa, Kentucky, and Wisconsin (Malvick and Grau 2001, Munkvold and Carlton 1995, Vincelli et al. 1994). Although Aphanomyces root rot was not recognised as an important disease of alfalfa until the 1980s, this and previous studies from other states indicate that $A$. euteiches is a widespread pathogen in the central US that may represent a greater risk to alfalfa and other legumes than is commonly recognised (Grau et al. 1991; Malvick and Grau 2001; Munkvold and Carlton 1995; Munkvold et al. 2001; Vincelli et al. 1994).

Two races of $A$. euteiches (R1 and R2) are known in the US. Results from this study demonstrate that both races 1 and 2 of $A$. euteiches are common across Illinois. Although R1 was the first race isolated and identified and has been used extensively to select alfalfa cultivars with resistance to Aphanomyces root rot, this study and others demonstrate that R2 is equally or more common in many areas of the central US including Illinois, Wisconsin, Iowa, Minnesota, and Kentucky (Malvick and Grau 2001; Munkvold et al. 2001). There were no apparent links between race and location of origin, suggesting that neither geographical factors nor environment were strongly associated with distribution of the two races. Although the risk of Aphanomyces root rot varies among fields due to multiple factors, the widespread occurrence of the pathogen suggests that many fields have the potential to develop this disease. Moreover, the widespread distribution of the R2 phenotype indicates that alfalfa cultivars with resistance only to $\mathrm{R} 1$ of $A$. euteiches are at widespread risk, and that cultivars with resistance to both races should be selected and sown in Illinois and other Midwestern states to limit losses due to Aphanomyces root rot. This is especially true in fields that are poorly-drained and have soils with a high clay content.
Because R2 was detected in fields where R1 resistant cultivars have not been planted, as well as in fields with no history of alfalfa production, it appears likely that both races are native and $\mathrm{R} 2$ has not evolved in response to selection pressure from R1-resistant cultivars. Although the data are not as clear, this study and others also suggest that there is variability in virulence among the isolates of $A$. euteiches on alfalfa germplasm, including some cultivars selected for resistance to $\mathrm{R} 2$ as well as germplasm with resistance to R2 such as WAPH-5 (Grau et al. 1991; Malvick and Grau 2001). Thus, the isolates used to screen for and evaluate resistance can affect the efficacy of resistance selected in alfalfa as they can in pea (Grau et al., 1991, Malvick and Percich, 1999; Wicker et al. 2001).

AFLP analysis revealed high levels of genetic diversity among the isolates from different fields and counties. However, populations from alfalfa fields lacked differentiation at the regional level. This analysis included 78 isolates from Illinois as well as smaller numbers of isolates from Wisconsin and North Carolina. Moreover, isolates from pea and alfalfa were commingled in the distance analysis presented in Fig. 2. Our results are similar to results from previous work where populations from pea showed high genotypic diversity; however they differed with regard to differentiation at the level of the individual field as well as the regional level (Grünwald and Hoheisel 2006; Malvick and Percich 1998). These results suggest that populations of $A$. euteiches from perennial alfalfa fields and annual pea fields have a different population structure.

Mechanisms for explaining the high genotypic diversity observed are likely to include occasional outcrossing and regular selfing, as this pathogen is homothallic (Grünwald and Hoheisel 2006; Shang et al. 2000). Aphanomyces euteiches appears to have a mixed mode of reproduction that includes clonality, selfing, and recombination as observed in other oomycetes (Grünwald et al. 2001; Prospero et al. 2007). As A. euteiches is soilborne, movement of individuals regionally occurs mostly through movement of soil. Given these observations, Grünwald and Hoheisel (2006) suggested that A. euteiches population structure is described by a model of 'genetic neighbourhoods'. In this model, recombination occurs at the field level, but gene as well as genotype flow occurs within fields (via tilling and water movement), 
between fields (movement of soil), and within a region (e.g., rare movement of soil).

Quite surprisingly, we did not find any relationship between race phenotype and AFLP genotype among the alfalfa isolates studied. The AFLP analysis randomly samples a large number of restriction sites across the genome. If race phenotype is determined by one localised genetic locus, a correlation between genotype and phenotype would only be observed if the AFLP locus and the race locus are linked (i.e., in close proximity) and if both loci are reasonably fixed. Our results may indicate that the differences between races involve a small part of the genome that was not sampled with the AFLP method used in this study. Conversely, multiple unlinked loci scattered across the genome could determine the race. Race could also be determined potentially by differences in gene expression in common genetic backgrounds. In previous work with phenotypically different isolates from pea, RAPD analysis differentiated isolates with different pathogenicity traits (Malvick and Percich 1998). More work is clearly needed to understand the pattern or genetic trait(s) that determines virulence phenotype.

Aphanomyces euteiches from Illinois alfalfa fields can infect and reproduce in a variety of native and cultivated legumes. In this study, 13 plant species susceptible to infection by isolates from alfalfa fields were identified. Moreover, this is the first report of seven legume hosts that are susceptible to isolates of A. euteiches from alfalfa fields: kura clover, purple prairie clover, white prairie clover, ladino clover, hairy vetch, Canadian milk vetch, and Illinois tick trefoil. Birdsfoot trefoil was found to be a non-host for this pathogen in this study and in previous studies (Beghdadi et al. 1992; Delwiche et al. 1987; Grau et al. 1991; Holub et al. 1991). Susceptibility and host range were defined based on the presence of root rot symptoms and oospores typical of A. euteiches infection in plants grown in clean vermiculite. Several of these host species are native to the central U.S. prairies, e.g., purple prairie clover, white prairie clover, Canadian milk vetch, and Illinois tick trefoil, suggesting that $A$. euteiches could be an indigenous pathogen there. The results represent an expanded host range based on good conditions for infection in a greenhouse where the pathogen could infect, reproduce, and cause symptoms in inoculated plants. It is not known how frequently these species are infected in field environments. Regardless, these results demonstrate that the number of forage legume species at potential risk from Aphanomyces root rot is greater than previously known, and they may also increase oospore inoculum in soil and the subsequent risk of Aphanomyces root rot of alfalfa in the same fields. There was no apparent difference in the host range of $\mathrm{R} 1$ and R2 isolates. With the exception of hairy vetch which was infected only by $\mathrm{R} 1$ isolates, all hosts were infected by both races

It is one thing to demonstrate the widespread presence A. euteiches, and another to understand its effect on establishment, growth, and yield of alfalfa and other legumes. Under field conditions in Kentucky, Aphanomyces root-rot resistant cultivars provided significantly increased seedling health and yield (Vincelli et al. 1995). Similar data are not available for Illinois where field trials failed to establish the effects of Aphanomyces resistance due to dry weather that occurred at the time of the trials. In Wisconsin and Iowa, cultivars with resistance to both races of $A$. euteiches had significantly greater yields than cultivars with no resistance or resistance only to $\mathrm{R} 1$ at a field location infested with R2 (Munkvold et al. 2001). Given the results from these and previous studies, deployment of resistance to both races may improve alfalfa establishment and production in many areas in the central US and perhaps beyond. Although the effects of Aphanomyces root rot on field performance of other legumes is not well known, results from this study suggest that this disease may be more common and cause damage to more legumes than is often recognised.

Acknowledgements We acknowledge the Illinois Council on Food and Agricultural Research for providing partial financial support to D. Malvick for this project. We thank M. MontezEllis, E. Grunden, G. Hoheisel and M. Larsen for excellent technical assistance. We also thank E. Adee, R. Bellm, B. Brink, D. Eplin, D. Feltes, O. Koester, J. Morrison, and M. Roegge for collection of soil samples. Parts of this research was done while D. Malvick was an Assistant Professor and A. Dyer was a Postdoctoral Research Associate in the Department of Crop Sciences at the University of Illinois at Urbana-Champaign.

\section{References}

Abbo, E. O., \& Irwin, J. A. G. (1990). Aphanomyces euteiches, a possible cause of poor lucerne establishment in the Lockyer Valley, Queensland. Australian Journal of Experimental Agriculture, 30, 361-364. doi:10.1071/EA9900361. 
Beghdadi, A., Richard, C., \& Dostaler, D. (1992). Aphanomyces euteiches in alfalfa fields of Quebec - isolation, morphology and variability of its growth and pathogenicity. Canadian Journal of Botany, 70, 1903-1911.

Delwiche, P. A., Grau, C. R., Holub, E. B., \& Perry, J. B. (1987). Characterization of Aphanomyces euteiches isolates recovered from alfalfa in Wisconsin. Plant Disease, 71, 155-161. doi:10.1094/PD-71-0155.

Fitzpatrick, S. Brummer, J., Hudelson, B., Malvick, D., \& Grau, C. (1998). Aphanomyces root rot resistance. In: Standard Tests to Characterise Alfalfa Cultivars, Third Ed. North American Alfalfa Improvement Conference.

Grau, C. R. (1992). Registration of WAPH-1 alfalfa germplasm with resistance to Aphanomyces root-rot. Crop Science, 32, 287-288.

Grau, C. R., Muehlchen, A. M., Tofte, J. E., \& Smith, R. R. (1991). Variability in virulence of Aphanomyces euteiches. Plant Disease, 75, 1153-1156.

Grünwald, N. J., \& Hoheisel, G.-A. (2006). Hierarchical analysis of diversity, selfing, and genetic differentiation in populations of the oomycete Aphanomyces euteiches. Phytopathology, 96, 1134-1141. doi:10.1094/PHYTO-961134.

Grünwald, N. J., Chen, W., \& Larsen, R. C. (2004). Pea diseases and their management. Dordrecht, The Netherlands: Kluwer.

Grünwald, N. J., Flier, W. G., Sturbaum, A. K., Garay-Serrano, E., van den Bosch, T. B. M., Smart, C. D., et al. (2001). Population structure of Phytophthora infestans in the Toluca valley region of central Mexico. Phytopathology, 91, 882-890. doi:10.1094/PHYTO.2001.91.9.882.

Grünwald, N. J., Goodwin, S. B., Milgroom, M. G., \& Fry, W. E. (2003). Analysis of genotypic diversity data for populations of microorganisms. Phytopathology, 93, 738746. doi:10.1094/PHYTO.2003.93.6.738.

Holub, E. B., Grau, C. R., \& Parke, J. L. (1991). Evaluation of the forma-specialis concept in Aphanomyces euteiches. Mycological Research, 95, 147-157.

Levenfors, J. P., Wikstrom, M., Persson, L., \& Gerhardson, B. (2003). Pathogenicity of Aphanomyces spp. from different leguminous crops in Sweden. European Journal of Plant Pathology, 109, 535-543. doi:10.1023/A:1024711428760.

Lynch, M., \& Milligan, B. G. (1994). Analysis of population genetic structure with RAPD markers. Molecular Ecology, 3, 91-99. doi:10.1111/j.1365-294X.1994.tb00109.x.

Malvick, D. K. (2002). Aphanomyces euteiches race 2 in central Illinois alfalfa fields. Plant Disease, 86, 560. doi:10.1094/ PDIS.2002.86.5.560A.

Malvick, D. K., \& Grau, C. R. (2001). Characteristics and frequency of Aphanomyces euteiches races 1 and 2 associated with alfalfa in the Midwestern United States. Plant Disease, 85, 740-744. doi:10.1094/PDIS.2001.85.7.740.

Malvick, D. K., \& Percich, J. A. (1998). Genotypic and pathogenic diversity among pea-infecting strains of Aphanomyces euteiches from the central and western United States. Phytopathology, 88, 915-921. doi:10.1094/ PHYTO.1998.88.9.915.

Malvick, D. K., \& Percich, J. A. (1999). Identification of Pisum sativum germ plasm with resistance to root rot caused by multiple strains of Aphanomyces euteiches. Plant Disease, 83, 51-54. doi:10.1094/PDIS.1999.83.1.51.
Malvick, D. K., Grau, C. R., \& Percich, J. A. (1998). Characterization of Aphanomyces euteiches strains based on pathogenicity tests and random amplified polymorphic DNA analyses. Mycological Research, 102, 465-475. doi:10.1017/S0953756297005029.

Munkvold, G. P., \& Carlton, W. M. (1995). Prevalence and distribution of Aphanomyces euteiches and Phytophthora medicaginis in Iowa alfalfa fields. Plant Disease, 79, 1251-1253.

Munkvold, G. P., Carlton, W. M., Brummer, E. C., Meyer, J. R., Undersander, D. J., \& Grau, C. R. (2001). Virulence of Aphanomyces euteiches isolates from Iowa and Wisconsin and benefits of resistance to $A$. euteiches in alfalfa cultivars. Plant Disease, 85, 328-333. doi:10.1094/ PDIS.2001.85.3.328.

Nei, M. (1978). Estimation of average heterozygosity and genetic distance from a small number of individuals. Genetics, 89, 583-590.

Papavizas, G. C., \& Ayers, A. R. (1974). Aphanomyces species and their root diseases in pea and sugarbeet, USDA-ARS.

Prospero, S., Hansen, E. M., Grünwald, N. J., \& Winton, L. M. (2007). Population dynamics of the sudden oak death pathogen Phytophthora ramorum in Oregon from 2001 to 2004. Molecular Ecology, 16, 2958-2973. doi:10.1111/ j.1365-294X.2007.03343.x.

Richard, C., \& Martin, J. G. (1991). Phytophora root rot of alfalfa in Quebec - geographic-distribution of the disease and associated soil factors. Phytoprotection, 72, 87-95.

Shang, H., Grau, C. R., \& Peters, R. D. (2000). Evidence of gene flow between pea and bean pathotypes of Aphanomyces euteiches. Canadian Journal of Plant Pathology, 22, 265275.

Steel, R. G., Torrie, J. H., \& Dickey, D. A. (1997). Principles and procedures of statistics. a biometrical approach. Third ed. (Boston: McGraw-Hill)

Stuteville, D. L., \& Erwin, D. C. (Eds.) (1990). Compendium of alfalfa diseases. Second edition. (St. Paul: APS)

Tamura, K., Dudley, J., Nei, M., \& Kumar, S. (2007). MEGA4: Molecular evolutionary genetics analysis (MEGA) software version 4.0. Molecular Biology and Evolution, 24, 1596-1599. doi:10.1093/molbev/msm092.

Tofte, J. E., Smith, R. R., \& Grau, C. R. (1992). Reaction of red clover to Aphanomyces euteiches. Plant Disease, 76, 3942.

Vandemark, G. J., Barker, B. M., \& Hughes, T. J. (2004). Heritability of resistance to Aphanomyces euteiches races 1 and 2 in alfalfa. Euphytica, 136, 45-50. doi:10.1023/B: EUPH.0000019518.62425.ba.

Vincelli, P., Lauriault, L. M., \& Henning, J. C. (1995). Yields of alfalfa varieties selected for Aphanomyces resistance in Kentucky. Agronomy Journal, 87, 748-752.

Vincelli, P., Nesmith, W. C., \& Eshenaur, B. C. (1994). Incidence of Aphanomyces euteiches and Phytophthora medicaginis in Kentucky alfalfa fields. Plant Disease, 78, 645-647.

Weir, B. S. (1996). Genetic data analysis. Sunderland, MA: Sinauer.

Wicker, E., Hulle, M., \& Rouxel, F. (2001). Pathogenic characteristics of isolates of Aphanomyces euteiches from pea in France. Plant Pathology, 50, 433-442. doi:10.1046/ j.1365-3059.2001.00590.x. 
Wicker, E., Moussart, A., Duparque, M., \& Rouxel, F. (2003).

Further contributions to the development of a differential set of pea cultivars (Pisum sativum) to investigate the virulence of isolates of Aphanomyces euteiches. European Journal of Plant Pathology, 109, 47-60. doi:10.1023/ A:1022020312157.
Wiersma, D. W., Undersander, D. J., \& Grau, C. R. (1997). Root heave of alfalfa cultivars with differing levels of resistance to Aphanomyces root rot. Agronomy Journal, 89, 148-150.

Wright, S. (1978). Evolution and the genetics of populations. Chicago: University of Chicago Press. 